\title{
Enrichment of Lassi by incorporation of peptides from whey protein concentrate
}

\author{
Preeti Paul* and Bikash C. Ghosh \\ -560030 , INDIA \\ *Corresponding author. E-mail: preetipaul.079@gmail.com \\ Received: April 22, 2017; Revised received: June 26, 2017; Accepted: November 1, 2017
}

Dairy Technology Department, Southern Regional Station, National Dairy Research Institute, Adugodi, Bengaluru

\begin{abstract}
Lassi is a refreshing beverage which is widely consumed throughout our country by people of all age groups. It is a reservoir of nutrients which are easily assimilable by the human body. The current study was initiated to increase functionality of Lassi by incorporation of hydrolyzed whey proteins. A solution of $10 \%$ whey protein was hydrolyzed to $7 \%$ degree of hydrolysis $(\mathrm{DH})$ using Flavorzyme at $50{ }^{\circ} \mathrm{C}$ for $30 \mathrm{~min}$. using $1: 25$ enzyme: substrate ratio. Calculated amount of cream and lactic acid were added to the hydrolyzate to bring the desired fat content and $\mathrm{pH}$ levels to that of Dahi. It was found that the hydrolyzate could be incorporated at $40 \% \mathrm{v} / \mathrm{v}$ level in Dahi without causing any adverse effect on the sensory attributes of Lassi. It was found that addition of sugar @15\% (w/w) of Lassi gave acceptable quality product. The average composition of optimized product was $-23.04 \%$ TS, $3.78 \%$ protein, $2.33 \%$ fat, $0.49 \%$ ash and $16.5 \%$ total carbohydrates. The average composition of control Lassi was - 22.8 $\%$ TS, $1.77 \%$ protein, $2.10 \%$ fat, $0.49 \%$ ash and $18.44 \%$ total carbohydrate. The presence of low molecular weight peptides in the optimized product using Tricine SDS-PAGE was confirmed. Enriched Lassi was found to have 79.67 $\%$ ACE inhibitory activity as opposed to $42.17 \%$ activity in control sample. It was found that non-thermized enriched Lassi sample had a shelf life of 9 days at $5+2{ }^{\circ} \mathrm{C}$ compared to 14 days for thermized sample.
\end{abstract}

Keywords: ACE inhibitory activity, Hydrolyzate, Lassi, Thermization, Whey protein concentrate

\section{INTRODUCTION}

Fermented foods are those foods which have been subjected to the action of microorganisms so that desirable biochemical changes occur, causing significant modifications to that food. Fermentation of milk is associated with several health benefits like enrichment with nutrients, flavour development, and properties like immune modulation, preservation, cholesterol reduction, restoration of intestinal microflora etc. (Sabikhi, 2006). Dahi is a fermented milk which is consumed widely throughout our country. It can be made into other variants like Lassi, Chaach (buttermilk), Kadhi, Shrikhand etc. Lassi is defined scientifically as a fermented milk beverage obtained after the growth of selected culture, usually lactic streptococci, in heat treated or partially whole milk followed by sweetening with sugar (Sabikhi, 2006). Milk has been identified as one of the main sources of protein for all age groups of humans. Two major whey proteins are found in whey namely $\alpha$ lactalbumin and $\beta$ - lactoglobulin. Apart from their obvious nutritive value, milk proteins and peptides exert a wide range of biological functions. Most of the proteins which are provento exhibit bioactive properties have originated from milk and its derivatives like immunoglobulins, caseins and whey proteins (Walther and Seiber, 2011).Native sequences of milk proteins may contain fragments that exert various activities, such as antihypertensive, antithrombotic, opioid, opioid antagonist, immunomodulatory, antibacterial, antifungal, antiviral, antioxidant, binding and transporting metals, preventing amnesia and causing smooth muscle contractions (Szwajkowska et al., 2011). Uses of these peptides have generated much interest among pharmaceutical and food industry. Studies have been undertaken to incorporate peptides into different foods (Bongers and Heimer, 1994; Papagianni, 2003; Pan et al., 2006; Jenny, 2007; Sarmadi and Ismail, 2010; Rajanbabu and Chen, 2011; Anuradha et al., 2013).

Anuradha et al. (2013) have evaluated antioxidant and physico-chemical characteristics of ice cream added with whey protein hydrolysate. The potential use of hydrolysed proteins in infant milk formulae to prevent the occurrence of allergies and food intolerance in infants has been reviewed by Osborn and Sinn (2009). Manninen (2004) has reviewed the importance of protein hydrolysates in sports nutrition. Protein hydrolyzate containing products have been specifically formulated for post exercise recovery. Jenny (2007) successfully enriched milk with functional peptides obtained by the hydrolysis of Whey Protein Concentrate (WPC). Peptide-rich hydrolysates are incorporated into Lassi, which is a beverage widely consumed in different variants and enjoyed by all age groups. Hydrolysate nor- 
mally, produces slight bitterness, however, fortification of peptides/ hydrolysatein Lassi is favourable because of its sweet and sour taste. Incorporation of peptides in Lassi, will enhance its nutritional profile, and increase availability of nutrients. The present study has the potential to open up a new variety of functional foods wherein foods already rich in their respective tastes can help in increasing the palatability of hydrolysates and support a higher percentage of incorporation. Generation of bioactive peptides was carried out by enzymatic hydrolysis of WPC. The slight bitterness caused by hydrolysis was masked by adding flavours which increased its palatability.

Therefore, the current research was planned and carried out to further enrich Lassi with peptides from whey protein hydrolysates.

\section{MATERIALS AND METHODS}

Hydrolysis of WPC (70\% protein - PROCON 3700 , M/s Mahaan Proteins Ltd., New Delhi) solutions (10 and $15 \%$ ) was carried out by enzymatic hydrolysis using 'Flavorzyme'(1000 LAPU/g, Novozymes South Asia Pvt. Ltd.). Hydrolysis was carried out at $\mathrm{pH}$ 7.0, in a water bath maintained at 500C. Degree of hydrolysis (\% DH) of 5, 7 and $10 \%$ and enzyme to substrate ratios of 1: 25, 1: 50 and 1: 100 were studied. Degree of hydrolysis was measured according to the $\mathrm{pH}$-stat technique as described by Adler-Nissen (1986). The WPC solutions $(5 \%, 10 \%$ and $15 \%$ whey protein solution) were preincubated at $50^{\circ} \mathrm{C}$ and the $\mathrm{pH}$ was adjusted to 7.0 using $0.5 \mathrm{~N} \mathrm{NaOH}$ followed by the addition of Flavourzyme enzyme at different E:S ratios of $1: 25,1: 50$ and 1:100. As hydrolysis proceeds, $\mathrm{pH}$ drops and correspondingly, more base $(\mathrm{NaOH})$ was added to maintain the $\mathrm{pH}$ at 7.0 and the base consumed was noted at 10 minutes interval. The amount of total base that would be consumed for a particular Degree of Hydrolysis (DH) was calculated using the formula given below and at that point the enzyme hydrolysis was stopped by heating the hydrolysate at $85^{\circ} \mathrm{C}$ for 10 min. The calculation of DH was done as follows and expressed as per cent.

$\% \mathrm{DH}=\mathrm{B} \times \mathrm{Nb} \times(1 / \alpha) \times(1 / \mathrm{MP}) \times(1 /$ htot $) \times 100$ where,

$\mathrm{B}=$ Base consumption in $\mathrm{ml}(\mathrm{NaOH})$,

$\mathrm{Nb}=$ Normality of the base $(0.5 \mathrm{~N})$,

$\mathrm{MP}=$ mass of protein in $\mathrm{g}$,

htot $=$ Total number of peptide bonds in the protein substrate (meq/g protein for whey protein; htot $=8.8$ ), $\alpha=$ Average degree of dissociation of the $\alpha-\mathrm{NH} 2$ groups.

These were computed by taking pKa values for different amino acids at various temperatures and $\mathrm{pH}$ as per table values shown in Table 7 .

Preparation of control Lassi: Fresh raw milk $(3.5 \pm 0.2 \%$ fat $)$ received from Experimental Dairy Plant, SRS of NDRI, Bangalore was pasteurized at 85
${ }^{0} \mathrm{C}$ for 10 min. This milk was cooled to $32-35^{\circ} \mathrm{C}$ and inoculated with $1 \%$ of Lactococcuslactis ssp. lactis culture and mixed for $5 \mathrm{~min}$. The milk was incubation at $30^{\circ} \mathrm{C}$ for $12-15 \mathrm{~h}$ till $0.70 \pm 0.05 \% \mathrm{LA}$ was achieved. The set Dahi was stirred manually to break the coagulum and sugar syrup was added at the rate of $15 \%$ (by weight of Dahi). Rose flavour (International Flavours and Fragrances) was then added at the rate of $0.1 \%$ (w/w of Lassi). All the ingredients were blended in a mechanical blender for $30 \mathrm{~s}$ for preparation of control Lassi.

Preparation of enriched Lassi: WPC solution (10\%, $15 \%$ ) was prepared and Flavourzyme was added at different enzyme to substrate ratios. A pH of 7.0 (by addition of $0.1 \mathrm{~N} \mathrm{NaOH}$ solution) and temperature of $50{ }^{\circ} \mathrm{C}$ was maintained throughout the duration of hydrolysis. The Degree of Hydrolysis (DH) wasmeasured after every $10 \mathrm{~min}$. interval. After achieving the desired DH, the enzyme activity was stopped by heating the hydrolysates at $85{ }^{\circ} \mathrm{C}$ for $10 \mathrm{~min}$ and then cooling the solution to $30 \pm 2{ }^{\circ} \mathrm{C}$. The fat percentage in hydrolysate was standardized to $3.5 \%$ by addition of calculated quantity of $40 \%$ fat cream. It was then added to Dahi in different proportions (30, 40 and $50 \% \mathrm{w} / \mathrm{w}$ of Dahi). Pasteurized chilled water was added to the mixture of Dahi and hydrolysate at the rate of $20 \% \mathrm{v} / \mathrm{v}$ of Dahi. Sugar syrup was added at the rate of $15 \%$ (by weight of Dahi). Rose essense was then added at the rate of $0.1 \%$ on Lassi basis followed by blending in a mechanical blender for preparation of final enriched Lassi.

Storage studies: Lassi $(200 \mathrm{ml})$ was packed in flexible pouches ( $60 \mu$ LDPE pouches) and stored under refrigeration $\left(5 \pm 2{ }^{\circ} \mathrm{C}\right)$. All the samples were subjected to sensory evaluation by a panel of eight judges when fresh and at regular intervals during storage using 9point hedonic scale (Stone and Sidel 2004). The yeast and mold count were also monitored at regular intervals during storage.

Thermisation of Lassi: The packaged pouches were thermized by placing them in a water bath maintained at $65^{\circ} \mathrm{C}$. The product was placed in the water bath till it attained a temperature of $65{ }^{\circ} \mathrm{C}$ for $5 \mathrm{~min}$. After this treatment, they were immediately cooled to room temperature, before storing under refrigeration $\left(5 \pm 2{ }^{\circ} \mathrm{C}\right)$.

Physico-chemical analysis: Total solids (TS), fat content, ash content and titratable acidity of Lassi were estimated according to the procedure mentioned in BIS (1981). The protein in Lassi was determined by standard MicroKjeldahl method as described in AOAC (2005). The $\mathrm{pH}$ of samples was measured using a digital pH meter (Digisun Electronics, Hyderabad, Model: DI 707). The apparent viscosity of Lassi samples (5 \pm 2 ${ }^{0} \mathrm{C}$ ) were determined using a rotational viscometer (Model RVDV-II Pro, Brookfield Engineering laboratory, Stoughton, MA) at various spindle speeds, in steps of $10 \mathrm{rpm}$, in a continuous run mode 
The consistency and index of viscosity of Lassi samples $\left(5 \pm 2{ }^{0} \mathrm{C}\right)$ were measured using TA.XT plus Stable Micro System, England. Lassi was filled in the specified container up to $3 / 4^{\text {th }}$ level and the probe (disc shaped) was allowed to travel into the sample under specified settings. Force for back extrusion was measured from a force-distance curve which gave empirical values for consistency and index of viscosity.

Identification of low molecular weight peptides using Tricine Sodium Dodecyl Sulphate Poly- Acrylamide Gel electrophoresis (Tricine - SDS PAGE): The presence of low molecular weight peptides was investigated using the method outlined by Schagger and Jagow (1987). Before loading samples on to a vertical acrylamide gel, the Protein content in hydrolysates and Lassi samples was determined as per the Lowry's method. The standard curve is illustrated in Figure 1.

Angiotensin converting enzyme (ACE) inhibition assay: Angiotensin converting enzyme (ACE) inhibitory activity was measured using the method suggested by Hernandez-Ledesma et al. (2003). The method is based on the liberation of hippuric acid from hippurylL-histidyl-L-leucine (HHL) catalyzed by ACE.

Sensory analysis: The enriched Lassi was analyzed for sensory characteristics at $8 \pm 2 \mathrm{C}$ by a trained panel of eight judges using a 9-point hedonic scale score

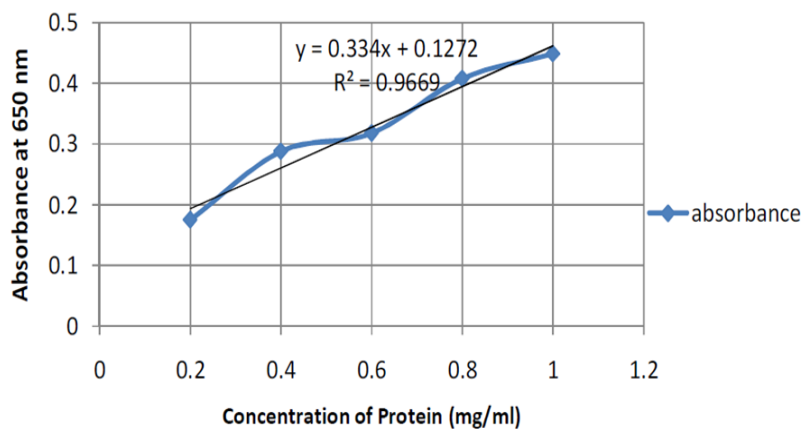

Fig. 1. Standard Curve for Estimation of protein by Lowry's Method.

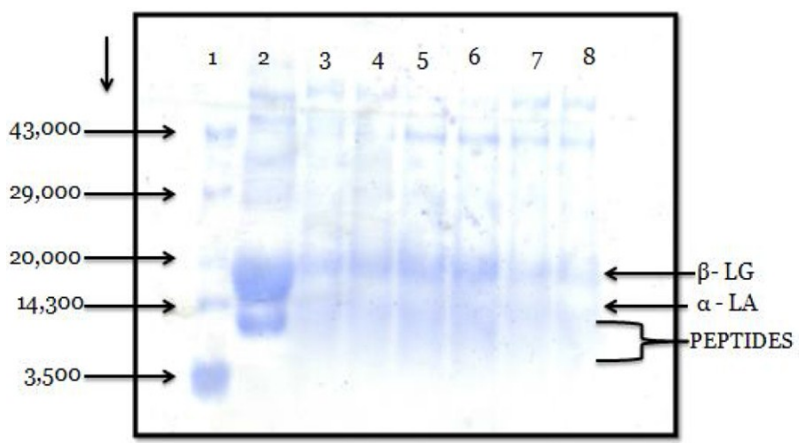

Fig. 2. Tricine - SDS - PAGE gel for $10 \% W P C$ solution hydrolyzed to different degree of hydrolysis. 1-Marker; 2WPC solution; 3,4 - Hydrolyzed WPC with $5 \% \mathrm{DH} ; 5,6$ Hydrolyzed WPC with $7 \%$ DH; 7,8 - Hydrolyzed WPC with $10 \% \mathrm{DH}$. card. All the samples were coded with a random 3digit number and the critical comments expressed by the judges were recorded.

Microbiological analysis: The coliform count and yeast and mold countswere estimated as per the methods stated in BIS (1981).

Statistical analysis: Data obtained during the present project work were subjected to statistical analysis for one way ANOVA using Microsoft Excel computer package.

\section{RESULTS AND DISCUSSION}

Standardization of procedure for enzymatic hydrolysis of WPC: The main parameters standardized for this study were concentration of the WPC solution, the enzyme to substrate ratio and degree of hydrolysis attained by the solution. Two combinations of WPC solutions i.e. 10 and $15 \%$ were prepared and two enzyme to protein ratio of 1:25 and 1:50 were evaluated at three different DH viz. 5, 7 and $10 \%$.

The time taken to hydrolyze different combinations of WPC solutions with varying enzyme to protein ratios to attain the desired $\mathrm{DH}$ is presented in Table 1 . It is observed in Table 1 that with the increase in concentration of protein solution,time taken to reach a given hydrolysis level increased. It can be seen from Table 1 that the DH has a significant effect $(p<0.05)$ on time

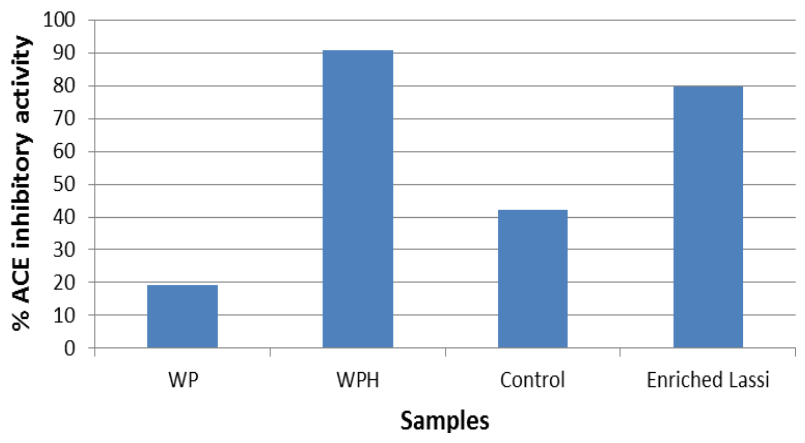

Fig. 3. ACE inhibitory activity in WPC, its hydrolyzate, control and enriched Lassi.

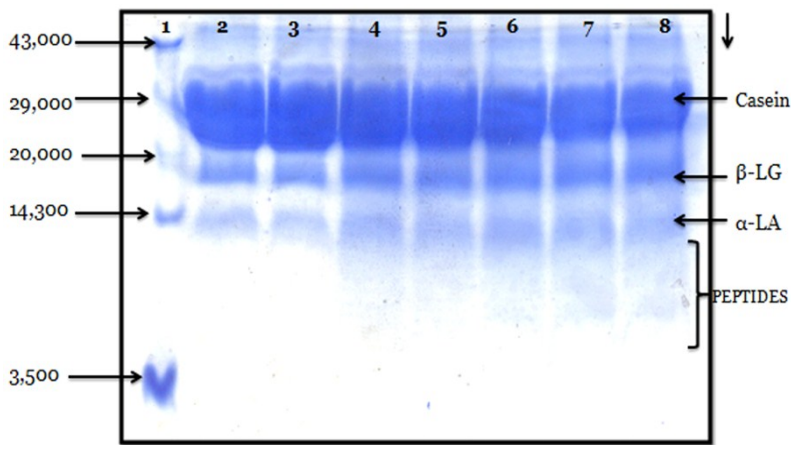

Fig. 4. Tricine - SDS PAGE of enriched Lassi with $10 \%$ protein hydrolyzate having $7 \%$ DH. 1 - Marker, 2 and 3 Control Lassi, 4 and 5- incorporation of 30\% (v/v) WPH, 6incorporation of $40 \%(\mathrm{v} / \mathrm{v}) \mathrm{WPH}, 7$ and 8 - incorporation of $50 \%(v / v) W P H$. 


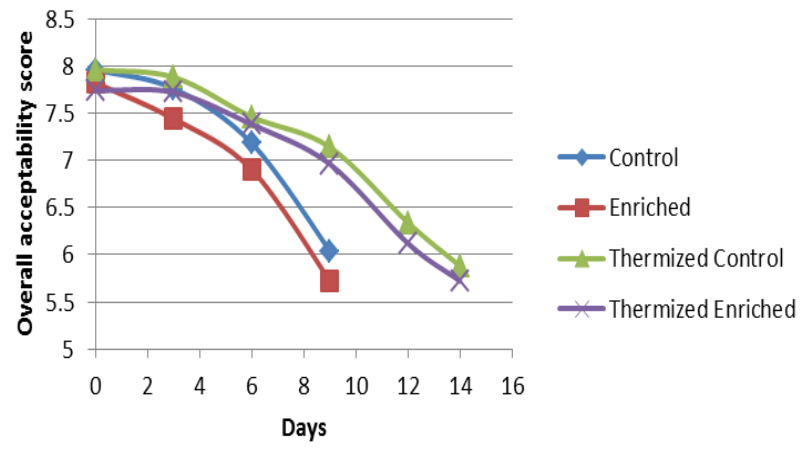

Fig. 5. Effect of storage on overall acceptability scores of Lassi samples.

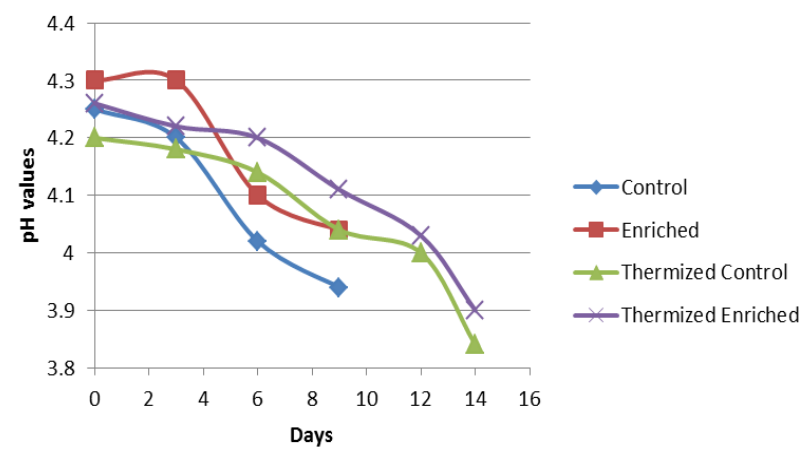

Fig. 6. Changes in $p H$ of Lassi during storage under refrigeration.

taken for hydrolysis. Between 10 and $15 \%$ protein solutions, the latter took more time to reach a particular DH although the enzyme to substrate ratio was same. The reaction was quick in the initial stages of hydrolysis since all susceptible bonds are attacked rapidly. Therefore, low degree of hydrolysis was achieved quickly for both the solutions of protein. As the hydrolysis activity progressed, strength of the enzyme tends to decrease since enzyme molecules have had reacted with all the available substrate sites. Therefore, it can be concluded that, as enzyme concen-

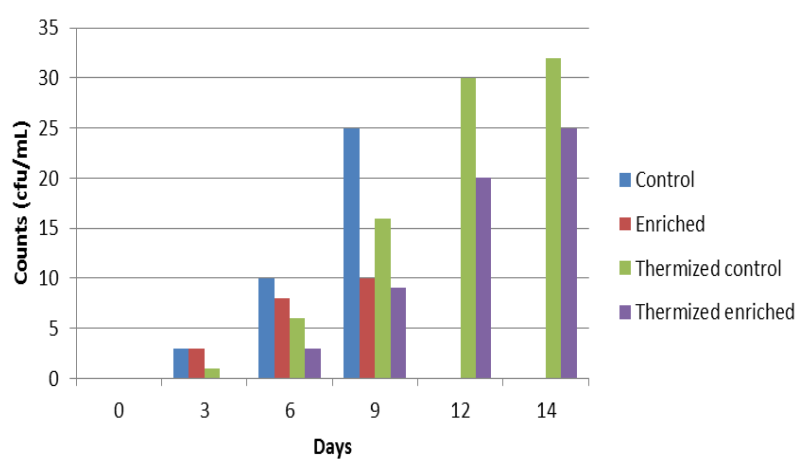

Fig. 7. Yeast and mold counts of different Lassi samples during storage study.

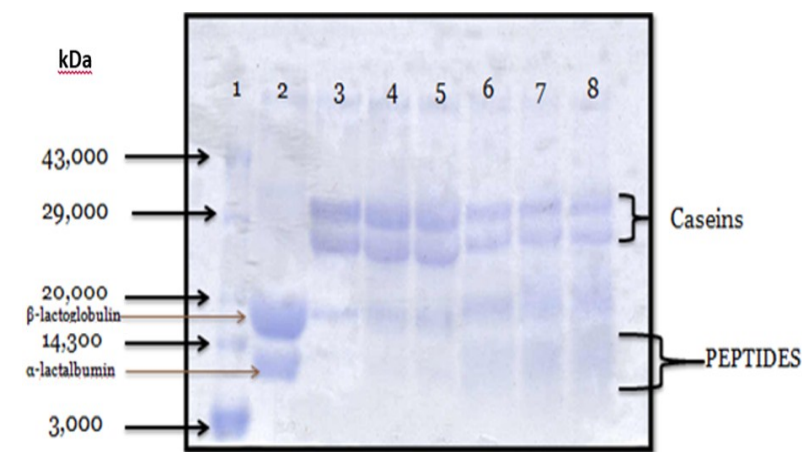

Fig. 8. Tricine - SDS PAGE of control and enriched Lassi with $10 \%$ protein.

tration increases, the time taken to achieve a particular degree of hydrolysis decreases. It was also observed that concentration of whey protein solution affects time taken to reach a particular degree of hydrolysis at same E:S ratio.

Effect of enzyme: substrate ratio on degree of hydrolysis in different protein concentrations at $\mathbf{3 0}$ min of hydrolysis: Time of hydrolysis is important for whey protein solutions because it is a conducive environment for bacterial growth and survival at $50^{\circ} \mathrm{C}$. Therefore, an attempt was made to observe degree of

Table 1. Time taken to hydrolyze different whey protein concentrations for desired degrees of hydrolysis with varying enzyme to substrate ratio.

\begin{tabular}{lcccc}
\hline & \multicolumn{4}{c}{ Hydrolysis time (min) } \\
\hline E : : & \% Protein solution & \multicolumn{3}{c}{ \% Degree of Hydrolysis } \\
\cline { 2 - 4 } & & 5 & 7 & 10 \\
\hline $1: 25$ & 10 & $17.25 \pm 0.82^{\mathrm{a}}$ & $30.10 \pm 1.15^{\mathrm{b}}$ & $79.00 \pm 1.22^{\mathrm{c}}$ \\
& 15 & $19.25 \pm 0.80^{\mathrm{a}}$ & $31.00 \pm 1.58^{\mathrm{b}}$ & $104.25 \pm 6.87^{\mathrm{c}}$ \\
$1: 50$ & 10 & $73.25 \pm 2.38^{\mathrm{a}}$ & $225.25 \pm 6.13^{\mathrm{b}}$ & $418.75 \pm 5.44^{\mathrm{c}}$ \\
& 15 & $80.00 \pm 3.53^{\mathrm{a}}$ & $260.50 \pm 6.57^{\mathrm{b}}$ & $465.75 \pm 3.76^{\mathrm{c}}$ \\
\hline
\end{tabular}

*E:S = Enzyme:Substrate, Values in the same row carrying different superscripts are significantly different $(p<0.05)$.

Table 2. Effect of enzyme to substrate ratio on degree of hydrolysis in different protein concentrations at $30 \mathrm{~min}$.

\begin{tabular}{llll}
\hline \multicolumn{5}{c}{ \% Degree of Hydrolysis } \\
\hline $\mathbf{E}: \mathbf{S}^{*}$ & $5 \%$ protein & $10 \%$ protein & $15 \%$ protein \\
$\mathbf{1}: \mathbf{2 5}$ & $7.73 \pm 0.05^{\mathrm{Cb}}$ & $7.09 \pm 0.15^{\mathrm{Ca}}$ & $6.88 \pm 0.28^{\mathrm{Ca}}$ \\
$\mathbf{1 : 5 0}$ & $4.52 \pm 0.19^{\mathrm{B} \mathrm{a}}$ & $4.34 \pm 0.15^{\mathrm{B} \mathrm{a}}$ & $4.05 \pm 0.10^{\mathrm{B} \mathrm{a}}$ \\
$\mathbf{1 : 1 0 0}$ & $2.50 \pm 0.15^{\mathrm{Aa}}$ & $2.38 \pm 0.08^{\mathrm{Aa}}$ & $2.55 \pm 0.39^{\mathrm{Aa}}$ \\
\hline
\end{tabular}

*E:S = Enzyme:Substrate, Values in the same row / columncarrying different superscripts are significantly different $(\mathrm{p}<0.05$, *Upper case denotes differences due to E:S, lower case denotes differences due to \%protein. 
Preeti Paul and Bikash C. Ghosh / J. Appl. \& Nat. Sci. 9 (4): 2391- 2399 (2017)

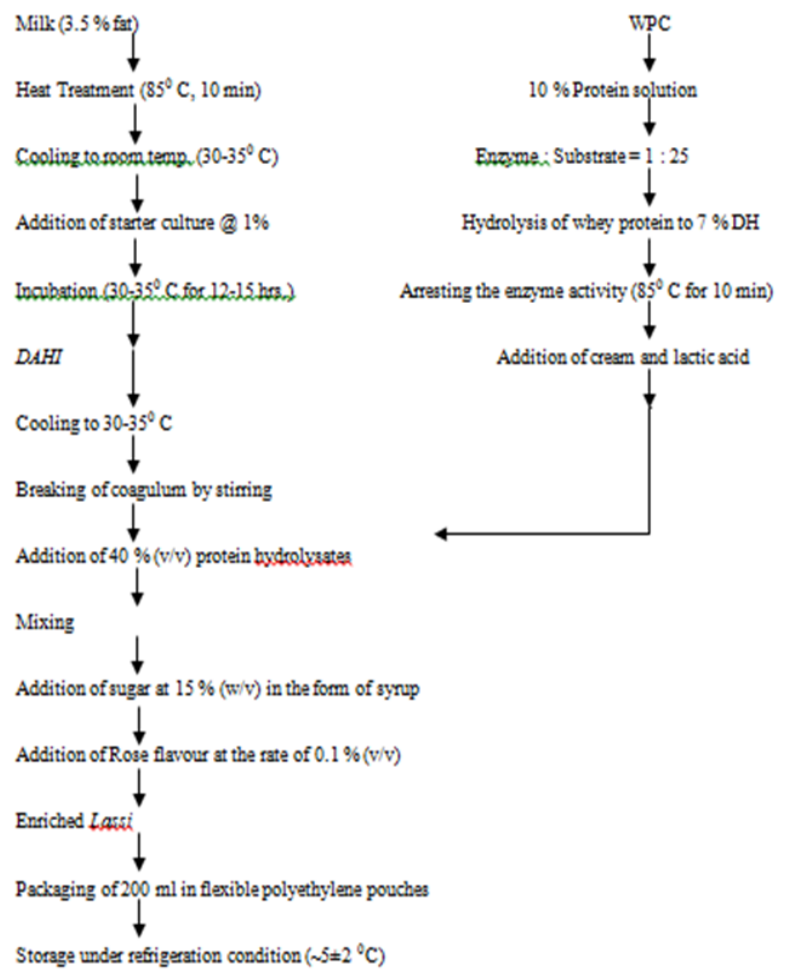

Fig. 9. Flow chart for preparation of experimental Lassi.

hydrolysis within a time limit of $30 \mathrm{~min}$ in different whey protein solutions to prevent the hydrolyzed protein solution against microbial spoilage and / or contaminants. This time limit seems to be feasible for industries which handle large volumes of hydrolyzed protein solutions as the time of hydrolysis is directly related with degree of hydrolysis. Therefore, enzyme
Table 3. Comparison of sensory scores* of Lassi incorporated with two types of hydrolysates.

\begin{tabular}{lll}
\hline Attributes & $\begin{array}{l}\mathbf{1 0 \%} \text { protein } \\
\text { hydrolysate\# }\end{array}$ & $\begin{array}{l}\mathbf{1 5 \%} \text { protein } \\
\text { hydrolysate\# }\end{array}$ \\
\hline Colour and appearance & $7.55 \pm 0.29$ & $7.80 \pm 0.08$ \\
Body and texture & $7.46 \pm 0.26$ & $7.53 \pm 0.11$ \\
Flavour & $7.50 \pm 0.19$ & $7.24 \pm 0.13$ \\
Sweetness & $7.57 \pm 0.18$ & $7.39 \pm 0.12$ \\
Overall acceptability & $7.50 \pm 0.20$ & $7.27 \pm 0.09$ \\
\hline
\end{tabular}

*average of 3 trials; \# DH $=7$, rate of addition of hydrolysate: $40 \%$ w/w of Dahi

to substrate ratios of 1:25 and 1:50 were used in different protein concentrations of 5, 10 and $15 \%$ to investigate the extent of hydrolysis occurred at the end of $30 \mathrm{~min}$.

Irrespective of the protein concentration, the enzyme to substrate ratio had a significant $(\mathrm{p}<0.05)$ influence on the degree of hydrolysis achieved at the end of 30 min. It can be seen from Table 2 that higher the quantity of enzyme used $(\mathrm{E}: \mathrm{S}$ ratio $=1: 25)$ higher was the $\% \mathrm{DH}$. The reason behind the above values may be that enzymeconcentration at a ratio of 1:25 is highest among the three ratios used. At high concentrations (1: 25$)$ there was a significant difference $(p<0.05, C D$ $=0.46$ ) between $5 \%$ protein solution with that of 10 and $15 \%$. Enzymes used in high concentrations immediately attack the susceptible protein sites resulting in rapid hydrolysis. Lowering the concentration of enzyme leads to slowing down of the entire reaction. Thus, it can be concluded that at the end of approximately $30 \mathrm{~min}$, about $7 \% \mathrm{DH}$ could be achieved in all the protein solution $(5,10$ and $15 \%)$ using enzyme to substrate ratio of 1:25.

Table 4. Effect of different sugar levels on the sensory evaluation of enriched Lassi.

\begin{tabular}{llll}
\hline $\begin{array}{l}\text { Rate of addition/ } \\
\text { Attributes }\end{array}$ & $\mathbf{1 0 \%}$ & $\mathbf{1 5 \%}$ & $\mathbf{2 0} \%$ \\
\hline Colour and appearance & $7.90 \pm 0.10^{\mathrm{a}}$ & $7.90 \pm 0.10^{\mathrm{a}}$ & $7.90 \pm 0.10^{\mathrm{a}}$ \\
Body and texture & $7.28 \pm 0.11^{\mathrm{a}}$ & $7.64 \pm 0.12^{\mathrm{b}}$ & $7.63 \pm 0.13^{\mathrm{b}}$ \\
Flavour & $7.28 \pm 0.17^{\mathrm{a}}$ & $7.72 \pm 0.08^{\mathrm{b}}$ & $7.65 \pm 0.09^{\mathrm{b}}$ \\
Sweetness & $7.38 \pm 0.08^{\mathrm{a}}$ & $7.72 \pm 0.08^{\mathrm{b}}$ & $7.60 \pm 0.07^{\mathrm{c}}$ \\
Overall acceptability & $7.34 \pm 0.11^{\mathrm{a}}$ & $7.64 \pm 0.10^{\mathrm{b}}$ & $7.61 \pm 0.11^{\mathrm{b}}$ \\
\hline
\end{tabular}

Note : Values with different superscripts in a row are significantly different $(\mathrm{p}<0.05)$

Table 5. Physico-chemical and microbiological characteristics of control and experimental Lassi.

\begin{tabular}{lll}
\hline Attributes (\%) & Control & Experimental \\
\hline Moisture & $77.2 \pm 0.21$ & $76.96 \pm 0.12$ \\
Protein & $1.77 \pm 0.32$ & $3.78 \pm 0.17$ \\
Fat & $2.10 \pm 0.08$ & $2.33 \pm 0.09$ \\
Ash & $0.49 \pm 0.01$ & $0.49 \pm 0.01$ \\
Total carbohydrate (by difference) & 18.44 & 16.5 \\
pH & $4.25 \pm 0.02$ & $4.29 \pm 0.19^{*}$ \\
Acidity (\% la) & $0.74 \pm 0.02$ & $0.72 \pm 0.01^{*}$ \\
Consistency (g.Sec) & $177.96 \pm 0.40$ & $159.65 \pm 1.32$ \\
Viscosity index (g.Sec) & $4.77 \pm 0.03$ & $4.20 \pm 0.08$ \\
Apparent Viscosity (cP) & $1031.00 \pm 0.35$ & $668.24 \pm 0.44$ \\
Coliform count (cfu/ml) & Nil & Nil \\
Yeast and mold count (CFU/ml) & Nil & Nil \\
\hline
\end{tabular}

*pH adjusted with lactic acid, Average of 3 trials 
Table 6. Final Formulation of Lassi.

\begin{tabular}{lll}
\hline Ingredients & Control & Enriched \\
\hline Stirred Dahi (3.5 \% fat) & 100 & 50 \\
$10 \%$ Hydrolyzed whey protein solution & - & 40 \\
Cream (40\%) & - & $10^{*}$ \\
Sugar & 15 & 15 \\
Water & 20 & 20 \\
Flavour (optional) & 0.1 & 0.1 \\
\hline
\end{tabular}

*Cream added to adjust fat level in hydrolyzate

Table 7. Calibration factors for the $\mathrm{pH}$-stat $(1 / \alpha)$.

\begin{tabular}{|c|c|c|c|c|c|}
\hline \multirow[b]{2}{*}{ pH } & \multicolumn{5}{|c|}{ Temperature (pK for amino groups) } \\
\hline & $25^{0} \mathrm{C}$ & $30^{0} \mathrm{C}$ & $40^{\circ} \mathrm{C}$ & $50{ }^{0} \mathrm{C}$ & $60^{0} \mathrm{C}$ \\
\hline 7.0 & - & 5.00 & 3.00 & 2.27 & 1.79 \\
\hline 7.5 & 2.59 & 2.27 & 1.63 & 1.40 & 1.25 \\
\hline 8.0 & 1.50 & 1.10 & 1.20 & 1.13 & 1.08 \\
\hline 8.5 & 1.16 & 1.13 & 1.06 & 1.04 & 1.03 \\
\hline 9.0 & 1.05 & 1.04 & 1.02 & 1.01 & 1.01 \\
\hline
\end{tabular}

(Adler-Nissen, 1986)

Identification of low molecular weight peptides in hydrolyzed WPC: Tricine -SDS-PAGE was carried out to identify the presence of different peptides in the hydrolysate at different degree of hydrolysis. Therefore, the hydrolysate samples of $10 \%$ WP solution with $\mathrm{DH}$ of 5, 7 and10 \% were prepared and loaded with $20 \mu \mathrm{L}$ samples containing protein concentration of 3.3-4 $\mu \mathrm{g} / \mu \mathrm{L}$ in each well. It was run at a constant voltage of $60 \mathrm{~V}$ till the dye reached the bottom of the gel. It was observed from the gel that lower molecular weight peptide bands are visible in all the samples except in whole WPC sample in lane 2 as seen in Figure 2.

The presence of two main protein fractions i.e $\beta$ - lactoglobulin $(18.4 \mathrm{KDa}$ )and $\alpha$ - lactalbumin (14.2 KDa) is distinct and clearly visible confirming the respective position as compared to the marker. Appearance of bands below $\alpha$ - lactalbumin (lane 3 to 8 ) is an indicative of the presence of peptides due to hydrolysis (Fig.2). As the DH increases, it was observed that intensity of $\beta$-lactoglobulin band decreases to a greater extent as compared to $\alpha$-lactalbumin band. Thus, it is clear that $\alpha$-lactalbumin is more resistant to hydrolysis by Flavourzyme as compared to $\beta$-lactoglobulin. This finding has been supported by the work of Gauthier and Pouliot (2003) who hydrolyzed whey proteins using trypsin. The examination of the peptide sequences revealed that the majority of the tryptic peptides originated from $\beta$-lactoglobulin, with only the sequence 105-108 from $\alpha$-lactalbumin. Britten and Giroux(1994) hydrolyzed WPC solution (6\% protein) using Rhozyme, a broad specificity protease from $\mathrm{As}$ pergillusoryzae. They found that Rhozyme did not attack $\alpha$-lactalbumin. On the other hand, half of the $\beta$ lactoglobulin content was hydrolyzed when the degree of hydrolysis reached 5.1\%. Schmidt and Poll (1991) hydrolyzed different fractions of whey protein using trypsin. They found that $\alpha$-lactalbumin was insensitive to the action of trypsin, while at the same time, $\beta$ lactoglobulin was rapidly hydrolyzed. Thus from the above discussion it can be concluded that maximum number of peptides are visible in hydrolysate with $7 \%$ $\mathrm{DH}$ and hydrolysis of $\beta$-lactoglobulin occurredto a greater extent than that of $\alpha$-lactalbumin.

Effect of incorporation of whey protein hydrolyzate on the sensory attributes of Lassi: Whey protein solutions of $10 \%$ and $15 \%$ were hydrolyzed to different $\mathrm{DH}$ viz. 5,7 and $10 \%$ at $50^{\circ} \mathrm{C}$, using enzyme : substrate ratio of $1: 25$. These three hydrolysates were added separately to Dahi at 30, 40 and $50 \%$ (w/w of Dahi) levels. Lactic acid was added to hydrolysates to adjust the $\mathrm{pH}$ within $4.18-4.32$ which were similar control Lassi.

The relevant results are presented in Table 3. Sensory evaluation of each combination revealed that flavour and overall acceptability were the most affected parameters. The least preferred sample was that of $10 \% \mathrm{DH}$. Extensive hydrolysis released bitterness causing peptides. The samples containing $10 \% \mathrm{DH}$ hydrolysates had the least palatability. Therefore they were eliminated from further investigation. In the other two cases, 5 $\% \mathrm{DH}$ could be incorporated to a level of $50 \% \mathrm{v} / \mathrm{v}(10$ $\%$ protein solution) and $40 \% \mathrm{v} / \mathrm{v}(15 \%$ protein solution). But it was previously noticed that Tricine SDS Page showed $7 \% \mathrm{DH}$ gave the maximum number of low molecular weight peptides. $7 \% \mathrm{DH}$ solution was found to be acceptable when added at a level of $40 \%$ $\mathrm{v} / \mathrm{v}$ to the Lassi. Finally the choice had to be made between $10 \%$ solution hydrolyzed to $7 \% \mathrm{DH}$ or $15 \%$ solution hydrolyzed to $7 \% \mathrm{DH}$. The sensory scores between the two were compared.

It was observed (Table 3 ) that the acceptability of Lassi enriched with $40 \%$ hydrolysate with $7 \% \mathrm{DH}$ from 10 $\%$ protein and $15 \%$ protein hydrolysates was very similar. The average flavour, sweetness and overall acceptability scores were lower in $15 \%$ protein hydrolysates 
incorporated Lassi as compared to that $10 \%$ protein hydrolysate incorporation. The palatability, taste and after tastes were better in $10 \%$ protein hydrolysate incorporated Lassi. Higher amount of protein in hydrolysate (15\% protein solution) may be reason behind this difference due to the presence of more number of bitter peptides. Therefore, incorporation of $10 \%$ protein hydrolysate with $7 \% \mathrm{DH}$ was recommended and incorporated at $40 \%$ level for the preparation of peptides enriched Lassi for better functionality.

Optimization of level of sugar: Since the hydrolysates were added into Lassi which was sour in taste, it was felt to determine the optimum level sugar for enriched Lassi which enhances its palatability. Three batches of enriched Lassi were prepared and sugar was added at 10,15 and $20 \% \mathrm{w} / \mathrm{w}$ of Dahi. It can be seen from Table 4 that level of sugar addition showed significant $(\mathrm{p}<0.05)$ influence on the flavour scores of enriched Lassi. There was no significant difference $(p>0.05)$ between the flavour scores of 15 and $20 \%$ sugar added Lassi. When sugar level was $10 \%$, least scores were obtained because it was not able to improve palatability of the enriched Lassi due to presence of hydrolysates which was responsible for an insipid taste of the end product. Overall acceptability scores were also significantly $(\mathrm{p}<0.05)$ influenced by the rate of sugar addition. Overall acceptability score of 7.34 was observed to be the lowest when $10 \%$ sugar was added into the enriched Lassi. But there was no significant $(\mathrm{p}<0.05)$ effect between scores of Lassi samples added with $15 \%$ and $20 \%$ sugar. Therefore, addition of $15 \%$ sugar was selected.

Physico-chemical and microbiological characteristics of control and enriched Lassi: Both the control and enriched Lassi were analysed for their physicochemical and microbiological attributes. From Table 5, it was observed that protein content in enriched Lassi is higher which is due to the addition of $40 \%$ hydrolysate from $10 \%$ whey protein solution. Milk fat content of control and enriched Lassi was 2.10 and $2.33 \%$ respectively. There was no difference in the ash content between the two samples. The higher total carbohydrate content in control Lassi could be attributed to higher amount of lactose content in control as compared to enriched Lassi. Average consistency values and viscosity indices obtained the samples were higher in control compared to enriched Lassi. The main reason may be due to the absence of casein in hydrolysate. There was a casein gel formation in control Lassi due to fermentation while enriched Lassi, containing $40 \%$ whey protein hydrolysate, did not contribute any gel matrix. Therefore proportionately, the casein gel content was lowered in the enriched Lassi. This led to decrease in the consistency and viscosity index values in enriched Lassi. Apparent viscosity in control was $1031 \mathrm{cP}$ while enriched Lassi, it was $668 \mathrm{cP}$. As discussed previously, added hydrolysate from WPC is probably responsible for a lower value in the enriched Lassi. Yeast and mold and coliform counts of both the samples were found to be nil.

Angiotensin-I-converting enzyme (ACE) inhibitory activity: ACE inhibitory activity in WPC, its hydrolyzate, control and enriched Lassi were compared. The maximum ACE-inhibition was obtained in the whey protein hydrolyzate $(90.66 \%)$ and the minimum was in whey protein solution (19.24\%) (Fig.3). The maximum activity could be attributed due to the peptides released after the action of Flavourzyme on the whey proteins whereas minimum may be due to the absence ofpeptides in whey protein solution. Control Lassi showed ACE-inhibition activities of $42.17 \%$. The presence of higher anti -hypertensive properties in enriched Lassi incorporated with $40 \%$ hydrolyzed whey protein compared to the control Lassi could be attributed to the presence of lower molecular peptides through added WPC hydrolysate into Lassi. Our observations are in agreement with the report of anti hypertensive activity in milk and milk products which can be generated by either fermentation or by enzymatic hydrolysis (Hernandez Ledesma et al., 2003). Heart rate lowering effects in spontaneously hypertensive rats has been reported through the feeding of fermented milks with Lactococcuslactis NRRLB-50571 and NRRLB-50572 (Nakamura et al., 1995). The present study also showed that $10 \%$ whey protein hydrolyzate with $\mathrm{DH}$ of 7\% had a good ACE-inhibiting activity. When incorporated into Lassi at an acceptable level of $40 \%$ (v/ v), it increased the ACE- inhibiting activity of the Las$s i$, thus improving its biological property of increased antihypertensive activity.

Figure 4 shows the differences in hydrolysis of milk protein fractions present in the different samples viz. control and enriched Lassi incorporated with 30, 40 and $50 \%$ hydrolysate. The absence of bands below $\alpha$ lactalbumin protein fractions in lane 2 and 3 indicate the absence peptides of low molecular weight in the control Lassi. Except the marker lane, all other lanes contain Lassi. Except in lane 1 (Marker), presence of casein fraction in all the samples is clearly visible in the range molecular weight between $23 \mathrm{kDa}-25 \mathrm{kDa}$. As level of incorporation increased from $30 \%$ (lane 4 and 5) to $40 \%$ (lane 6) and 50\% (lane 7 and 8 ), occurrences of peptides below $\alpha$-lactalbumin protein fractions were visible reflecting the presence lower molecular weight peptides in the enriched Lassi. Thickness of the casein, $\beta$-lactoglubulin and $\alpha$ lactalbuminbands is observed to be less from lane 5 to lane 8 as the amount of hydrolyzate incorporation increased and it is maximum thin in lane 8 where $50 \%$ incorporation was carried out. Therefore, Lassi with the maximum incorporation $(50 \%)$ of hydrolyzate shows presence of maximum concentration of peptides (lane -7 and 8 ).

The method of preparation of enriched Lassi has been 
outlined in Figure 9. The final formulation of Lassi has been shown in Table 6 .

Effect of storage on Sensory attributes: Both the Control and enriched Lassi were stored at refrigeration temperature i.e. $5 \pm 2{ }^{0} \mathrm{C}$. The relevant results are presented in Figure 5. As the storage time elapsed, visible changes started occurring in the samples. The most obvious change was separation of fat in enriched Lassi samples while whey was separated at the surface in control Lassi. Both the changes can be overcome once the pouches were shaken properly before consumption. Viscosity of both the control samples was observed to decrease and the mouth feel appeared to be watery. As the storage duration progressed, flavours in all the samples gradually changed to a very strong and pungent acidic flavour. Enriched Lassi samples had a very insipid flavour because of the presence of hydrolysates as compared to control Lassi. Sensory evaluation of the non-thermized Lassi showed a decrease in sensory scores from initial 7.96 to 6.04 in control and from 7.82 to 5.72 for enriched Lassi after $9 \mathrm{~d}$ storage and both became unacceptable.

Similarly, spoilage was also observed in both the thermized Lassi samples. But the rate of spoilage was slow as heat treatment was given to both samples initially. At the end of $14 \mathrm{~d}$, overall acceptability scores were 5.88 for control and 5.72 for enriched Lassi and both the products were unacceptable.

Effect of storage on the $\mathbf{p H}$ values: The changes in average $\mathrm{pH}$ values of the samples showed a decreasing trend with the increase in storage periods irrespective of type samples and their treatments. In the case of non-thermized Lassi samples, the $\mathrm{pH}$ values of control decreased from 4.25 on day 0 to 3.51 on day 12 . Similarly $\mathrm{pH}$ values of non-thermized enriched Lassi decreased from 4.30 on day 0 to 3.80 on day 12 (Fig. 6). But between the two samples, the $\mathrm{pH}$ of enriched Lassi showed lower decrease compared to control sample. This can be attributed to lower microbial spoilage due tothe presence of anti-microbial properties of hydrolyzed protein in enriched Lassi.

Both the thermized Lassi showed a slow decrease in the $\mathrm{pH}$ values during storage from day 0 to day 14 . Thermization resulted in the improvement of shelf life of these samples. Proteolysis due to psychrotrophic bacteria were expected to be lower as some these organisms were destroyed by thermization treatment. Therefore, the reduction in $\mathrm{pH}$ values were found to be slower. $\mathrm{pH}$ values of thermized enriched Lassi, decreased slowly from 4.26 to 3.9 during storage. Anti-microbial effect of hydrolysates could also be responsible for a better shelf life as reflected by the $\mathrm{pH}$ values in thermized enriched Lassi.

Effect of storage under refrigeration on the Yeast and mold count of Lassi samples: Yeast and mould counts of all the four samples showed an increasing trend during entire period of storage. Though the ini- tial yeast and mold counts of all the four samples were nil, the count was observed after 3 days of storage onwards. It was observed that rate of growth was more in both the non thermized samples than in thermized samples for the same period of storage. The counts were 25 in controland $10 \mathrm{cfu} / \mathrm{mL}$ in enrichedLassi on 9th day of storage and products were unacceptable whereas thermized Lassi became unacceptable after 14th dayof storage. The yeast and mould counts were 32 and 25 $\mathrm{cfu} / \mathrm{mL}$ in control and enriched Lassi, respectively (Fig. 7).

The gradual increase in the yeast and mold count could be related to dormant yeast and mold spores which were activated after $\mathrm{pH}$ of Lassi samples decreased during storage. As the storage period progressed, the counts also were found to increase. At the end of storage duration, it was observed that counts for enriched Lassi were lower than that of control Lassi in both thermized and non- thermized samples. This may be due to anti-microbial properties of hydrolysate. The hydrolyzed protein may have inhibited the growth of yeast and mold which resulted in a lower counts in both the enriched Lassi sample. In similar studies Bolscher et al. (2012) reported that the candidacidal properties of a chimeric peptide derived from Lactoferrin was found to possess a strikingly killing activity against Candida albicans. Puknun et al. (2013) also reported that a heterodimer comprised of two bovine lactoferrin antimicrobial peptides exhibits powerful bactericidal activity against Burkholderia pseudomallei, a Gram negative, aerobic, soil dwelling bacterium. Electrophoretic study of stored Lassi: Protein hydrolysis takes places even during storage of fermented products due to the presence of microorganisms. It was felt to study the eletrophoretic analysis to evaluate the further hydrolysis of protein during storage and status of peptides profile present in the enriched Lassi during storage. Therefore, fresh, stored and spoiled $(10 \mathrm{~d}$ old) samples were analysed for comparison. The fresh whey protein solution ( lane 2) did not show any casein fraction and peptides and only bands for $\beta$ lactoglobulin $(18.4 \mathrm{kDa})$ and $\alpha$ - lactalbumin $(14.2 \mathrm{kDa})$ were easily visible (Fig.8). Lane 3 (fresh controlLassi) which has no hydrolyzate, did not show any prominent bands below $\alpha$ - lactalbumin. Stored control Lassi (lanes 4 and5) showed the appearance diffused bands of casein fractions as well as presence of small amount of whey proteins fractions. This indicates further hydrolysis of casein and whey proteins during storage due toexcessive microbial fermentation during storage. Whey protein bands (lane 4 and 5) were diffused which was sharp in fresh sample (lane 3). This resulted in diffused bands which were lighter in intensity. Fresh enriched Lassi ( lane 6) showed the presence of sharp casein bands compared to that 10 days old stored enriched Lassi (lane 7 and 8) and the bands appeared little hazy. Main differences between fresh and spoiled 
Lassi were observed in whey protein bands. Spoilage due to excess fermentation had resulted in diffused bands of $\beta$-lactoglobulin and $\alpha$ - lactalbumin. The presence of a thick diffused band below $\alpha$ - lactalbumin in the spoiled samples indicate it got affected to a great extent during storage.

\section{Conclusion}

From the study conducted, it can be concluded that a health beverage like Lassi can be prepared by incorporating whey protein hydrolysates for better functionality. Though there could be changes in flavor, palatability can be improved using the right type of permitted additives. . The presence of low molecular weight peptides in the optimized product using Tricine SDSPAGE was confirmed. In the conducted project, Lassi enriched with $40 \%$ hydrolysates with $7 \% \mathrm{DH}$ was found to have ACE inhibitory activity of $79.67 \%$ as opposed to $42.17 \%$ activity in control sample, which will benefit consumers in controlling hypertension... It was found that non-thermized enriched Lassi sample had a shelf life of 9 days at $5 \pm 2{ }^{0} \mathrm{C}$ compared to 14 days for thermized sample. This shelf life can be marginally extended by thermization treatment at $65{ }^{\circ} \mathrm{C}$ for 5 min. Thus, the developed enriched Lassi containing lower molecular weight peptides and ACE inhibitory effects could have a considerable market potential in current times as consumers have started to realize the benefits of functional foods.

\section{REFERENCES}

Adler-Nissen, J. (1986). Enzymic hydrolysis of food proteins, Elsevier, New York.

Anuradha, K., Mann, B., Saini, P., Singh, R. R. B., Kumar, R. and Sharma, R. (2013). Assessment Of Antioxidant And Physico-Chemical Characteristics Of Ice Cream Added With Whey Protein Hydrolysate. Indian Journal of Dairy Science, 66(5):382-387.

AOAC (2005) Official methods of analysis of AOAC international. 18th edn, Washington D.C.

Bolscher, J., Nazmi, K., van Marle, J., vant Hof, W. and Veerman, E. (2012). Chimerization of lactoferricin and lactoferrampin peptides strongly potentiates the killing activity against Candida albicans. Biochemistry and Cell Biology, 90: 378 - 388.

Bongers, J., \& Heimer, E. P. (1994). Recent applications of enzymatic peptide synthesis. Peptides, 15(1) : 183-193.

Britten, M. and Giroux, H.J. (1994). Effect of pH during heat processing of partially hydrolyzed whey proteins. Journal of Dairy Science, 77:676-684.

Gauthier, S.F. and Pouliot, Y. (2003). Functional and biological properties of peptides obtained by enzymatic hydrolysis of whey proteins. Journal of Dairy Science, 86: (E. Suppl.):E78-E87.

Hernandez-Ledesma, B., Alvarez, P.J.M. and Pueyo, E. (2003). Assessment of the spectrophotometric method for determination of Angiotensin-I-Converting Enzyme activity: Influence of the inhibition type. Journal of Agriculture and Food Chemistry, 51: 4175-4179.

BIS (1981) IS: (SP: 18)ISI Handbook of Food Analysis. Part
XI: Dairy Products. Indian Standards Institution, New Delhi.

Jenny, J.A. (2007). Enrichment Of Milk With Functional Peptides From Hydrolyzed Whey Proteins, Ph.D. Thesis submitted to NDRI Deemed University, Karnal.

Manninen, A. H. (2004). Protein hydrolysates in sports and exercise: a brief review. Journal Of Sports Science \& Medicine, 3(2): 60.

Nakamura, Y., Yamamoto, N., Sakai, K., Okubo, A., Yamazaki, S. and Takano, T. (1995). Purification and characterization of angiotensin I-converting enzyme inhibitors from sour milk. Journal of Dairy Science, 78:777783.

Osborn, D. A. and Sinn, J. K. H. (2009). Formulae containing hydrolysed protein for prevention of allergy and food intolerance in infants - A Review. The Cochrane Library, Issue 1, Vol18:3664.

Pan, Y., Lee, A., Wan, J., Coventry, M. J., Michalski, W. P., Shiell, B., \& Roginski, H. (2006). Antiviral properties of milk proteins and peptides. International Dairy Journal, 16(11) : 1252-1261.

Papagianni, M. (2003). Ribosomally synthesized peptides with antimicrobial properties: biosynthesis, structure, function, and applications. Biotechnology advances, 21 (6) : 465-499.

Puknun, A., Bolscher, J. G. M., Nazmi, K., Veerman, E. C. I., Tungpradabkul, S. and Wongratanacheewin, S., (2013). A heterodimer comprised of two bovinelactoferrin antimicrobial peptides exhibits powerful bactericidal activity against Burkholderiapseudomallei. World Journal of Microbiology and Biotechnology, 29:1217-1224.

Rajanbabu, V. and Chen, J. Y. (2011). Applications of antimicrobial peptides from fish and perspectives for the future. Peptides, 32(2) : 415-420.

Sabikhi, L. (2006). Developments in the manufacture of Lassi. In : Souvenir - Short course on " Developments in Traditional Dairy Products" held at Centre of Advanced Studies , Dairy Technology Division, NDRI, Karnal, Pg : 64.

Sarmadi, B. H. and Ismail, A. (2010). Antioxidative peptides from food proteins: a review. Peptides, 31(10) : 19491956.

Schagger, H. and Jagow, G.V. (1987). Tricine-Sodium Dodecyl Sulfate-Polyacrylamide Gel Electrophoresis for the separation of Proteins in the Range from 1 to 100 kDa. Analytical Biochemistry, 166: 368-379.

Schmidt, D. G. and Poll, J. K. (1991). Enzymatic hydrolysis of whey proteins. Hydrolysis of $\alpha$-lactalbumin and $\beta$ lactoglobulin in buffer solutions by proteolytic enzymes. Netherlands Milk and Dairy Journal, 45:225240.

Stone, H. and Sidel, J. L. (2004). Discrimination testing - 5. In Sensory Evaluation Practices ( $3^{\text {rd }}$ ed., pp. 145 - 200). Academic Press.

Szwajkowska, M., Wolanciuk, A., Barłowska, J., Król, J., and Litwinczuk, Z. (2011). Bovine milk proteins as the source of bioactive peptides influencing the consumers' immune system-a review. Animal Science Papers and Reports, $29: 269-280$.

Walther, B. and Sieber, R. (2011). Bioactive proteins and peptides in foods. International Journal for Vitamin and Nutrition Research, 81(23) : 181-192. 